\title{
Genetic health messages in the mass media: Do the general public perceive non-personalized genetic health message as personally relevant?
}

Citation for published version (APA):

Smerecnik, C. M. R., Mesters, I., Candel, M. J., de Vries, H., \& de Vries, N. K. (2010). Genetic health messages in the mass media: Do the general public perceive non-personalized genetic health message as personally relevant? British Journal of Health Psychology, 15(Pt4), 941-956. https://doi.org/10.1348/135910710X494574

Document status and date:

Published: 01/11/2010

DOI:

10.1348/135910710X494574

Document Version:

Publisher's PDF, also known as Version of record

\section{Document license:}

Taverne

\section{Please check the document version of this publication:}

- A submitted manuscript is the version of the article upon submission and before peer-review. There can be important differences between the submitted version and the official published version of record.

People interested in the research are advised to contact the author for the final version of the publication, or visit the DOI to the publisher's website.

- The final author version and the galley proof are versions of the publication after peer review.

- The final published version features the final layout of the paper including the volume, issue and page numbers.

Link to publication

\footnotetext{
General rights rights.

- You may freely distribute the URL identifying the publication in the public portal. please follow below link for the End User Agreement:

www.umlib.nl/taverne-license

Take down policy

If you believe that this document breaches copyright please contact us at:

repository@maastrichtuniversity.nl

providing details and we will investigate your claim.
}

Copyright and moral rights for the publications made accessible in the public portal are retained by the authors and/or other copyright owners and it is a condition of accessing publications that users recognise and abide by the legal requirements associated with these

- Users may download and print one copy of any publication from the public portal for the purpose of private study or research.

- You may not further distribute the material or use it for any profit-making activity or commercial gain

If the publication is distributed under the terms of Article 25fa of the Dutch Copyright Act, indicated by the "Taverne" license above, 


\title{
Copyright (C) The British Psychological Society
}

Reproduction in any form (including the internet) is prohibited without prior permission from the Society

\section{Genetic health messages in the mass media: Do the general public perceive non-personalized genetic health message as personally relevant?}

\author{
Chris M. R. Smerecnik*, Ilse Mesters, Math J. J. M. Candel, \\ Hein de Vries and Nanne K. de Vries \\ School for Public Health and Primary Care (Caphri), Department of Health \\ Promotion, Faculty of Health, Medicine and Life Sciences, Maastricht University, \\ The Netherlands
}

\begin{abstract}
Objectives. Although health messages communicating the role of genetics in health and disease development are increasingly prevalent in our society, no research has examined whether the general public perceives such messages as believable or personally relevant. We examined whether the general public accepted genetic health messages and viewed them personally relevant in promoting their preventive behaviour.

Design. Experimental pre-test-post-test measurement design was employed to contrast the information acceptance and perceived personal relevance of the genetic health message with a general health message.

Methods. We presented a randomly selected group of Dutch participants $(N=$ I, 3/9) with either a health message about the genetic risk factors for salt sensitivity or with a general health message about salt sensitivity without reference to genetic risk factors. Risk perception and intention to restrict salt intake was assessed before and after participants read the messages while information acceptance and perceived personal relevance was only assessed post-test.
\end{abstract}

Results. Although we observed no effects of health message type on information processing, previously aware participants perceived the genetic health message as less personally relevant compared to the general health message. This difference in personal relevance resulted in lower estimates of susceptibility and a lower intention to engage in preventive behaviour among previously unaware participants.

Conclusions. Genetic health messages in the mass media may not be effective in promoting (intentions to engage in) preventive behaviour due to their low perceived personal relevance by the public. Hence, identifying strategies to increase personal relevance for genetic education is needed.

\footnotetext{
* Correspondence should be addressed to Chris M. R. Smerecnik, School for Public Health and Primary Care (CAPHRI), Department of Health Promotion, Faculty of Health, Medicine and Life Science, Maastricht University, PO Box 616, 6200 MD Maastricht, The Netherlands (e-mail: c.smerecnik@gvo.unimaas.nl).
} 


\section{Copyright (C) The British Psychological Society \\ Reproduction in any form (including the internet) is prohibited without prior permission from the Society}

\section{Chris M. R. Smerecnik et al.}

Recent advances in genomics have been suggested to radically transform the public health landscape (Collins, Green, Guttmacher, \& Guyer, 2003). Indeed, technological and biochemical applications of genomics have proved to be successful in identifying individual members of the general population who are at increased risk for a given disease due to their genetic makeup. Since the completion of the Human Genome project in 2003, more than 350 genetic tests are available (National Institutes for Health, 2009) and approximately 450 tests are currently in development (NCBI, 2009). Such genetic services have been proven successful in improving risk perception (Meiser \& Halliday, 2002; Smerecnik, Mesters, Verweij, de Vries, \& de Vries, 2009) and reducing anxiety (Butow, Lobb, Meiser, Barratt, \& Tucker, 2003).

Several authors have suggested that the value of such applications of genomics can be greatly enhanced by educating the general public about genetics (Burke et al., 2002; Wang, Bowen, \& Kardia, 2005). Media coverage of genetics has been quite extensive in the USA (cf. Bubela \& Caulfield, 2004). Our preliminary analyses suggest that this is also true in The Netherlands. Approximately, 1,000 news stories were distributed in daily newspapers and news broadcasts in 2008 alone. A recent controversy surrounding embryo selection, which even reached the Dutch House of Parliament, received substantial media attention.

The effect of such communications about genetics has been heavily debated with opponents arguing that media coverage of genetics may lead to beliefs of genetic determinism (e.g., Katz Rothman, 1998) while proponents argue that beliefs about genetic causation have remained rather consistent despite massive media attention (e.g., Condit et al., 2009). Unfortunately, there is scarce empirical research into the effects of mass media health messages about genetics on persuasion and precautionary action (Saab et al., 2004). The little evidence that is available suggests that communicating the existence of genetic risk factors to the general public (cf. Rogers, 2003) does not necessarily lead to interest in obtaining a genetic test (Cappella, Lerman, Romantan, \& Baruh, 2005) or to motivation to engage in preventive behaviour (Smerecnik, Mesters, de Vries, \& de Vries, 2009).

In their study, Cappella et al. (2005) presented smokers with a message about the role of genes in smoking addiction or with a message about the gender of smokers' offspring. The genetic message did not affect perceived susceptibility or the intention to get a genetic test. Interestingly, Cappella et al. (2005) did observe an interaction effect between message type and the believability of the genetic message to affect intentions to get a genetic test. This effect seemed to be mediated by perceived susceptibility. These results illustrate the importance of a genetic message's believability.

However, concerns have been raised concerning the public's willingness to accept genetic health messages. Genetic health messages that imply genetic determinism are not likely to be accepted by the majority of the general population (Condit, 2005). People seem to believe that although genes have some influence in disease development, this influence can be countered by their personal efforts, behaviour, or religious forces. Messages that run counter to these beliefs are either rejected outright or reinterpreted in such a way that the influence of genes is one of many in the multifactorial causation dimension (Condit, 2005). Either way, such message may not be perceived as credible. Considering these issues and the findings of Cappella et al. (2005), our first goal was to examine whether the general public accepts genetic health messages as credible and believable compared to general health messages.

Besides issues of genetic health message's believability, the perceived personal relevance of the genetic health message may be a factor that determines the effects of 


\section{Copyright (C) The British Psychological Society \\ Reproduction in any form (including the internet) is prohibited without prior permission from the Society}

mass media genetic health messages on persuasion and precautionary action. The primary driving force behind the positive effects of genetic testing and counselling is argued to lie in its ability to individualize risks by referring to individual differences in DNA structure (Guttmacher \& Collins, 2005; Janssens \& Van Duijn, 2008). However, the mass media inevitably lack such individuation qualities as it directs genetic health messages at the general public at large. As such, genetic health message recipients may not be convinced of the personal relevance of this message. So, besides examining whether the general public accepts genetic health messages as credible and believable, our second goal was to investigate whether the general public perceives genetic health messages as personally relevant. Additionally, we were also interested in whether and how information acceptance and personal relevance could explain the adverse effects of genetic health messages on perceived susceptibility as observed in previous research (Cappella et al., 2005; Smerecnik, Mesters, de Vries, et al., 2009), which was our third goal.

Concerning our first goal (i.e., examine whether genetic health messages communicating the existence of genetic risk factors for multifactorial disease are accepted by the general public as credible and believable), we formulated two hypotheses. We expected individuals who were unaware at the time of information exposure (i.e., individuals who had not heard of the existence of genetic risk factors for a given medical condition prior to this study) to be less inclined to accept a genetic health message as believable compared to a general health message (Hypothesis 1) as the genetic health message contains new information with which they are not familiar. The opposite effect was expected for aware individuals (i.e., individuals who had heard of the existence of genetic risk factors for a given medical condition prior to this study). Aware participants might view a general message with suspicion since it does not mention genetics as a cause for disease that they know to be true (cf. Frewer, Howard, Hedderley, \& Shepherd, 1999). As such, the general health message may be less likely to be perceived as credible or believable as compared to the genetic health message (Hypothesis 2). Our second goal was to examine whether the general public perceives genetic health messages as personally relevant. We expected that among previously unaware participants, the general health message will be perceived to be more personally relevant compared with the genetic health message (Hypothesis 3). Among previously aware participants, we did not expect differences between the genetic and general health message in terms of perceived personal relevance (Hypothesis 4). Concerning our third goal, we explored the possible mediating or moderating effects of information acceptance and personal relevance in explaining the effects of genetic health messages on perceived susceptibility.

\section{Method \\ Participants}

We approached 2,500 individuals for the present study through an Internet research company, named Flycatcher (see http://www.flycatcher.eu for more information). This research company is affiliated with Maastricht University. The panel consists of 20.000 members of the Dutch general public over 12 years of age. From this database, the Internet research company selected a subsample of 2,500 individuals which would be representative of the Dutch general population in terms of age, gender, and level of education. After participants filled out a questionnaire, they received a financial reward 


\section{Copyright (C) The British Psychological Society \\ Reproduction in any form (including the internet) is prohibited without prior permission from the Society}

\section{Chris M. R. Smerecnik et al.}

in line with those typically given to panel members (approximately $\$ 2.50$ ). They could obtain an additional bonus by completing all questionnaires, making the total reward approximately $\$ 10$.

\section{Procedure}

The Internet consumer panel sent e-mails to the 2,500 individuals selected for the study. These individuals were selected to form a sample representative of the Dutch general population. The e-mail message contained an Internet link to a login page, which expired after 1 week. After logging into their account, participants could fill out the socio-demographics questionnaire, containing measures of several socio-demographic characteristics and awareness status of the genetic risk factors for salt sensitivity. When finished with the questionnaire participants were automatically relocated to the consumer panel's homepage. Two weeks later participants who filled out the sociodemographics questionnaire were sent a second e-mail inviting them for the baseline questionnaire. The baseline questionnaire contained (pre-test) measures of susceptibility, severity, and intention to restrict salt intake. An additional 2 weeks later participants that filled out the baseline questionnaire were sent a third e-mail inviting them to fill out the immediate follow-up questionnaire. Participants were randomly assigned to first receive one of two health messages (communicating the existence of genetic risk factors for salt sensitivity or communicating general information about salt sensitivity without reference to genetic risk factors). The health message was presented on screen and participants were led to believe that the message was an article from a large daily newspaper. After reading the health message, participants were asked to answer questions regarding information acceptance, personal relevance and (post-test) measures of susceptibility, severity, and intention.

\section{Materials}

The present scenarios and the questionnaires were adopted from previous research (Smerecnik, Mesters, de Vries, et al., 2009). One health message presented information on the existence of genetic risk factors for salt sensitivity whereas the other health message presented general information on salt sensitivity without reference to its genetic risk factors (see Appendix). Note that this does not entail providing personalized DNA risk information, but rather involves simply communicating the fact that salt sensitivity is partly caused by genetic factors. We chose salt sensitivity for two reasons. First, a number of different genetic variants have recently been discovered that seem to be causally involved in this phenomenon (Beeks, Kessels, Kroon, Van der Klauw, \& De Leeuw, 2004; Sanada et al., 2006). Second, research has shown that a majority of the general public may not be aware of the existence of genetic risk factors of salt sensitivity (Smerecnik, Mesters, de Vries, et al., 2009). Considering these two issues, the health messages may thus accurately represent mass media articles of recently discovered genetic predispositions.

\section{Measures}

Socio-demographics questionnaire

In the socio-demographics questionnaire, participants were asked to report the following demographic characteristics: bypertension status ('Are you currently diagnosed with hypertension?' $1=$ no, $2=y e s$ ), whether they presently were on a 


\title{
Copyright (C) The British Psychological Society
}

\author{
Reproduction in any form (including the internet) is prohibited without prior permission from the Society
}

salt-restricted diet $(1=$ no, $2=y e s)$, and whether they had a family bistory of cardiovascular disease (CVD) and family bistory of bypertension ('Are one or more members of your direct family diagnosed with cardiovascular disease/hypertension?' $1=$ no, 2 = don't know, $3=$ yes).

Awareness status was assessed using one forced-choice item ('Have you ever heard of genetic risk factors for a salt-sensitive blood pressure?' $1=y e s, 0=n o$ ). Participants' age, gender, and level of education were available through the Internet consumer panel.

\section{Baseline questionnaire}

Risk perception was operationalized by assessing perceived susceptibility to and perceived severity of salt sensitivity. Perceived susceptibility of having a salt-sensitive blood pressure was measured using three items assessing absolute perceptions of susceptibility (e.g., 'I am vulnerable to a salt-sensitive blood pressure', $1=$ totally disagree to $7=$ totally agree) and three items assessing perceptions of risk relative to others (e.g., 'Relative to your peer group, how large is your chance of having a salt sensitive blood pressure', $1=$ much smaller to $7=$ much larger). Exploratory factor analysis revealed one single underlying factor (eigenvalue $=3.80 ; R^{2}=.76$ ). These six items were therefore combined into the susceptibility factor (Cronbach's $\alpha=.91$, $M=4.63, S D=1.24$ ). Severity was assessed by three items (e.g., 'Salt sensitivity is a serious medical condition', $1=$ totally disagree to $7=$ totally agree; Cronbach's $\alpha=.87, M=2.67, S D=1.22$ ). The intention to restrict salt intake was assessed using three items (e.g., 'I intend to restrict my salt intake', $1=$ totally disagree to $7=$ totally agree; Cronbach's $\alpha=.93, M=3.17, S D=1.52$ ).

\section{Immediate follow-up questionnaire}

In the immediate follow-up questionnaire, participants first read the health message and were then asked to fill out questions regarding information acceptance and perceived personal relevance. Information acceptance was assessed by four items (e.g., 'The information in the message was believable', 'The information in the message was accurate', $1=$ totally disagree $-7=$ totally agree; Cronbach's $\alpha=.77, M=4.86$, $S D=1.25$ ). Perceived personal relevance was measured using two items (e.g., 'The information was personally relevant', 'The information is applicable to me personally', $1=$ totally disagree $-7=$ totally agree; Cronbach's $\alpha=.76, M=3.66, S D=1.48$ ). Afterwards participants answered the same questions on perceived susceptibility (Cronbach's $\alpha=.93, M=3.39, S D=1.24$ ), severity (Cronbach's $\alpha=.87, M=2.75$, $S D=1.29$ ), and intention (Cronbach's $\alpha=.94, M=4.41, S D=1.67$ ) as in the baseline questionnaire.

\section{Statistical analyses}

Initial analyses were conducted to examine whether the general health message versus the genetic health message groups and the aware versus unaware groups differed in terms of the socio-demographic variables. Possible confounding variables (i.e., those variables on which the experimental or the aware vs. unaware groups differed) were added as covariates in all subsequent analyses. To examine the effects of the health messages on information acceptance and personal relevance, we conducted two regression analyses with information acceptance and personal relevance as the dependent variables and health message type, awareness status, and their interaction as independent variables. 


\section{Copyright (C) The British Psychological Society}

Reproduction in any form (including the internet) is prohibited without prior permission from the Society

Chris M. R. Smerecnik et al.

To replicate previous findings on the effects of genetic health messages on intention, we examined whether the effect of health message type on intention was mediated or moderated by susceptibility by performing the procedure outlined in Fairchild and MacKinnon (2009), using the Mplus software package (Muthen \& Muthen, 2006). The same procedure was then used to examine the possible mediating or moderating effects of information acceptance and personal relevance on perceived susceptibility.

\section{Results}

\section{Sample characteristics}

In total, 1,319 participants filled out all three questionnaires. Table 1 presents the demographic characteristics of the initial $(N=2,500)$ and the final sample $(N=1,319)$. The final sample seemed to be higher educated than the general population but accurately reflects the general population in terms of gender and age.

Table I. Demographic characteristics of the initial and final research sample

\begin{tabular}{|c|c|c|c|c|c|}
\hline \multirow[b]{2}{*}{ Demographic characteristics } & \multicolumn{2}{|c|}{$\begin{array}{l}\text { Initial sample } \\
(N=2,500)\end{array}$} & \multicolumn{2}{|c|}{$\begin{array}{l}\text { Final sample } \\
(N=1,319)\end{array}$} & \multirow{2}{*}{$\begin{array}{l}\text { Dutch population data } \\
(\%)^{\mathrm{a}}\end{array}$} \\
\hline & $\%$ & $N$ & $\%$ & $N$ & \\
\hline \multicolumn{6}{|l|}{ Gender } \\
\hline Male & 48 & 1,200 & 48.7 & 642 & 49.4 \\
\hline Female & 52 & 1,300 & 51.3 & 677 & 50.6 \\
\hline \multicolumn{6}{|l|}{ Age } \\
\hline 20-39 years & 35 & 875 & 30.3 & 399 & 34.8 \\
\hline 40-64 years & 45 & 1,125 & 51.4 & 714 & 46.2 \\
\hline$\geq 65$ years & 20 & 500 & 15.6 & 206 & 19.1 \\
\hline \multicolumn{6}{|l|}{ Level of education } \\
\hline Low & 30 & 750 & 31.8 & 419 & 33.4 \\
\hline Medium & 42 & 1,050 & 38.9 & 513 & 41.0 \\
\hline High & 28 & 700 & 29.3 & 387 & 25.6 \\
\hline
\end{tabular}

${ }^{a}$ Statistics Netherlands (CBS), Voorburg/Heerlen, 2007 (Retrieved from http://www.cbs.nl). Data of Dutch population $\geq 20$ years for gender and age, and data $\geq 15$ years for level of education.

We observed no differences between the genetic health message $(N=654)$ and general health message groups $(N=665)$ in terms of age, gender, level of education, hypertension status, family history of CVD, family history of hypertension, whether they were on a salt-restricted diet or not, and awareness status $(\phi$ 's $>.11)$. The aware $(N=235)$ versus the unaware group $(N=1,084)$ did not differ in terms of age, gender, hypertension status, and whether they were on a salt-restricted diet $(\phi$ 's $>.23)$. However, aware participants were more likely to be higher educated $(\mathrm{OR}=1.27$, $p=.01)$, and more likely to be unaware of their family history of CVD (OR $=0.72$, $p<.01$ ). Consequently, all subsequent analyses were controlled for level of education, and family history of CVD.

\section{Information acceptance}

Regression analysis did not reveal a significant effect of bealth message type, awareness or the bealth message type by awareness interaction effect on information acceptance 


\section{Copyright (C) The British Psychological Society}

Reproduction in any form (including the internet) is prohibited without prior permission from the Society

Table 2. Regression analyses of health message type and awareness on information acceptance, personal relevance, susceptibility, and intention

\begin{tabular}{|c|c|c|c|c|c|c|c|c|c|c|}
\hline & \multicolumn{2}{|c|}{$\begin{array}{l}\text { Information } \\
\text { acceptance }\end{array}$} & \multicolumn{2}{|c|}{$\begin{array}{l}\text { Personal } \\
\text { relevance }\end{array}$} & \multicolumn{2}{|c|}{ Severity } & \multicolumn{2}{|c|}{ Susceptibility } & \multicolumn{2}{|c|}{ Intention } \\
\hline & $\beta$ & $\Delta R^{2}$ & $\beta$ & $\Delta R^{2}$ & $\beta$ & $\Delta R^{2}$ & $\beta$ & $\Delta R^{2}$ & $\beta$ & $\Delta R^{2}$ \\
\hline Step I & & .002 & & $.010 * *$ & & $.190 * *$ & & $.220 * *$ & & $.410^{* * *}$ \\
\hline HM type & -0.03 & & -0.03 & & -0.01 & & 0.03 & & 0.05 & \\
\hline Awareness & -0.04 & & $-0.09 * *$ & & 0.03 & & $-0.13 * *$ & & $-0.08^{*}$ & \\
\hline Step 2 & & .001 & & $.003 *$ & & .000 & & $.010 *$ & & $.003 *$ \\
\hline HM type & -0.17 & & $-0.29 *$ & & -0.06 & & -0.35 & & $0.25 *$ & \\
\hline Awareness & -0.07 & & $-0.15^{* *}$ & & 0.02 & & $-0.2 I^{* *}$ & & $0.08 *$ & \\
\hline $\begin{array}{l}\text { HM type } \times \\
\text { awareness }\end{array}$ & 0.15 & & $0.28^{*}$ & & 0.05 & & $0.50^{*}$ & & $-0.27^{*}$ & \\
\hline
\end{tabular}

Note. The regression analyses were controlled for level of education and family history of CVD. Additionally, the analyses on severity, susceptibility, and intention were controlled for the pre-test measures of severity, susceptibility, and intention, respectively; $* p<.05 ; * * p<.01$.

( $\beta$ s $<0.15, p$ s $>.10$, see Table 2 ). In other words, the genetic health message was accepted as well as the general health message by both previously aware and previously unaware participants.

\section{Personal relevance}

Regression analyses revealed a significant main effect of awareness on personal relevance, $\beta=-0.09, p=.01$ (see Table 2 ). However, this effect seemed to be qualified by a bealth message type by awareness interaction effect, $\beta=0.28, p=.04$ (see Figure 1). In depth analyses revealed a significant negative effect of bealth message

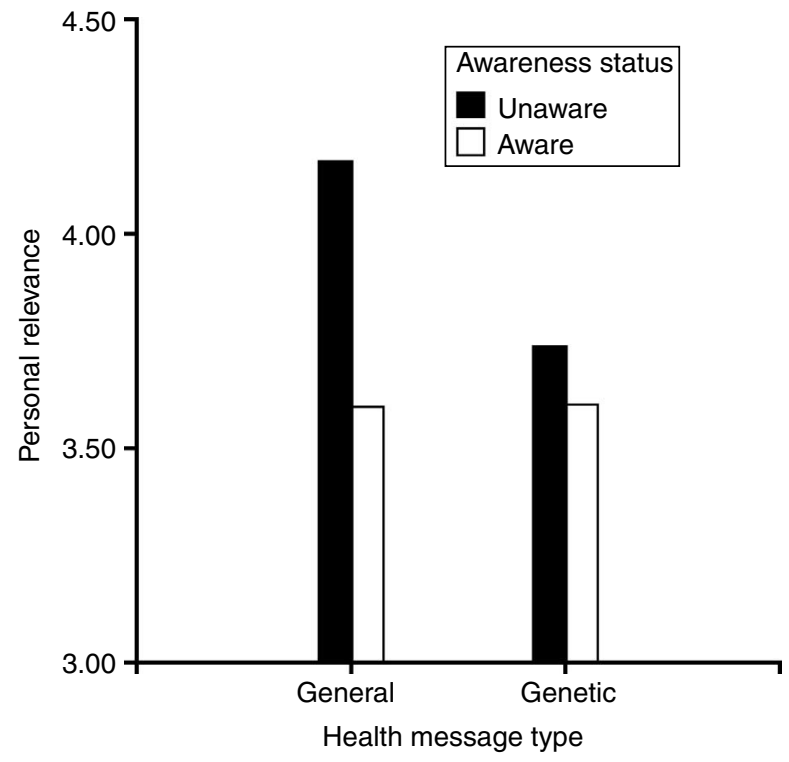

Figure I. Personal relevance scores for previously aware versus previously unaware individuals categorized by health message type. 


\section{Copyright (C) The British Psychological Society}

Reproduction in any form (including the internet) is prohibited without prior permission from the Society

type on personal relevance among previously unaware individuals, $\beta=-0.14, p=.03$, but not among previously aware participants, $\beta=-0.01, p=.95$. Previously unaware participants perceived the general scenario information as more personally relevant $(M=4.17, S D=1.58)$ than the genetic scenario information $(M=3.74, S E=1.46)$. In addition, previously unaware participants reading the general health message (HM) also reported higher personal relevance than previously aware participants who read the general health message $(M=3.60, S D=1.46, p<.001)$ and previously aware participants who read the genetic health message $(M=3.61, S D=1.46, p<.001)$. No other significant effects were observed on this measure.

\section{Mediation and moderation analyses}

Since we did not observe any effects of health message or awareness status on information acceptance, the mediation and moderation analyses were only conducted for personal relevance. To replicate previous findings of the effects of genetic health messages on intention (Cappella et al., 2005; Smerecnik, Mesters, de Vries, et al., 2009), we first explored whether the effects of health message type and awareness status on intention were mediated or moderated by perceived susceptibility (see Figure 2). The model that we tested was also based on the regression analyses and the correlations between the outcome measures (see Tables 2 and 3). We observed a significant effect of the health message by awareness status interaction on susceptibility $(\beta=0.30, p=.03)$

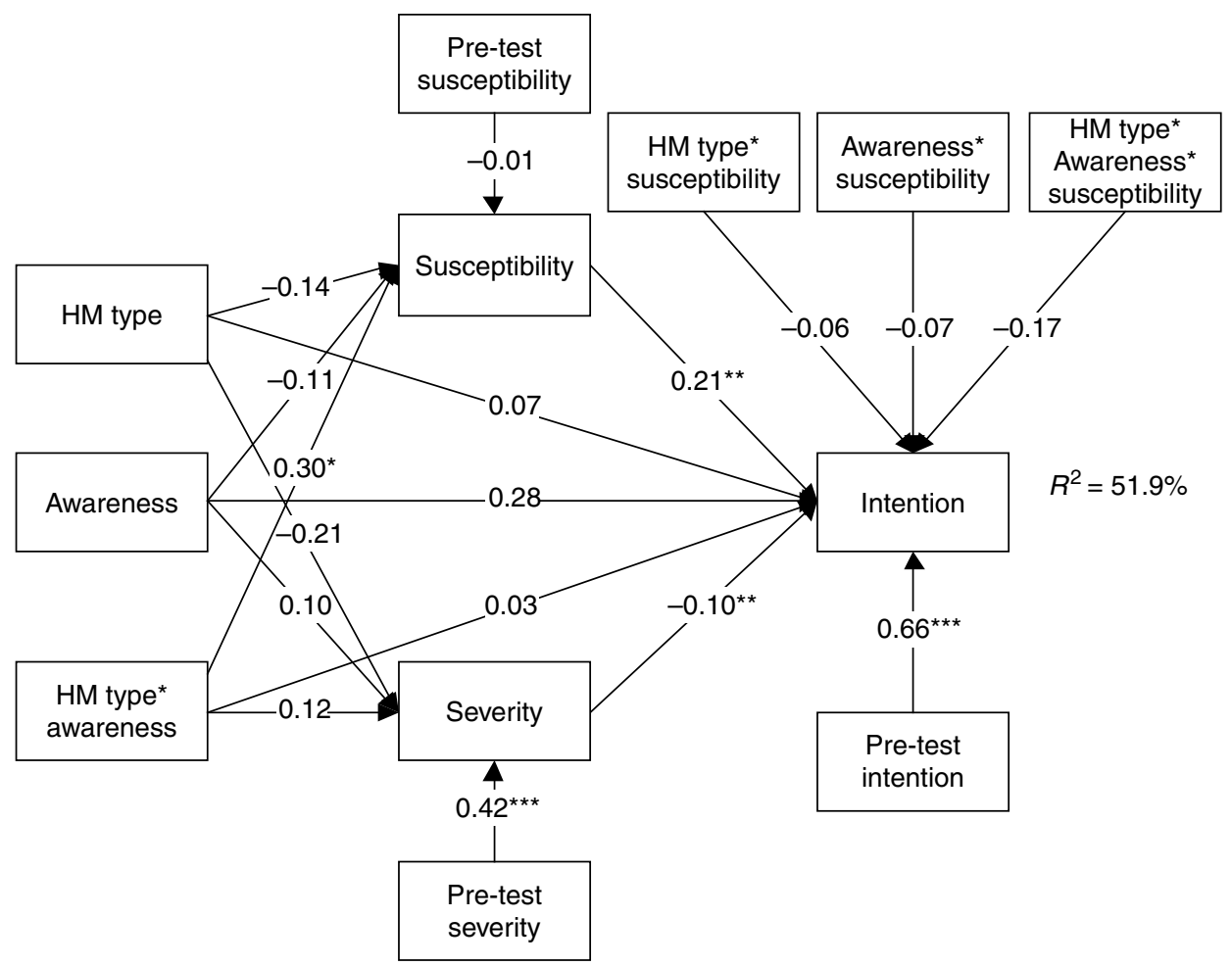

Figure 2. General model for testing mediation and moderation effects of susceptibility in the health message-intention relationship. ${ }^{*} p<.05 ;{ }^{* *} p<.01$; ***p $<.001$. 


\title{
Copyright (C) The British Psychological Society
}

\author{
Reproduction in any form (including the internet) is prohibited without prior permission from the Society
}

Table 3. Correlation matrix of information acceptance, personal relevance severity, susceptibility, and intention

\begin{tabular}{|c|c|c|c|c|c|c|c|c|}
\hline & \multirow[b]{2}{*}{$\begin{array}{l}\text { Information } \\
\text { acceptance }\end{array}$} & \multirow[b]{2}{*}{$\begin{array}{l}\text { Personal } \\
\text { relevance }\end{array}$} & \multicolumn{2}{|c|}{ Severity } & \multicolumn{2}{|c|}{ Susceptibility } & \multicolumn{2}{|c|}{ Intention } \\
\hline & & & Pre-test & Post-test & Pre-test & Post-test & Pre-test & Post-test \\
\hline $\begin{array}{l}\text { Information } \\
\text { acceptance }\end{array}$ & I & & & & & & & \\
\hline $\begin{array}{l}\text { Personal } \\
\quad \text { relevance }\end{array}$ & $.28 * *$ & I & & & & & & \\
\hline \multicolumn{9}{|l|}{ Severity } \\
\hline Pre-test & $.17 * *$ & $-.17 * *$ & I & & & & & \\
\hline Post-test & $.20 * *$ & $-.20 * *$ & $.44 * *$ & I & & & & \\
\hline \multicolumn{9}{|l|}{ Susceptibility } \\
\hline Pre-test & .03 & -.03 & -.03 & .02 & I & & & \\
\hline Post-test & $-.66 * *$ & $.61^{* *}$ & $-.15^{* *}$ & $-.21 * *$ & -.03 & I & & \\
\hline \multicolumn{9}{|l|}{ Attitude } \\
\hline Pre-test & -.05 & $.14^{*}$ & $-.18 * *$ & $-.20 * *$ & .05 & .03 & & \\
\hline Post-test & $-.07 * *$ & $.20 * *$ & $-.16 * *$ & $-.22 * *$ & .01 & .07 & & \\
\hline \multicolumn{9}{|l|}{ Intention } \\
\hline Pre-test & $-.25^{* *}$ & $.27 * *$ & $-.17 * *$ & $-.17^{* *}$ & -.01 & $.18 * *$ & I & \\
\hline Post-test & $-.31 * *$ & $.33 * *$ & $-.17 * *$ & $-.21 * *$ & -.01 & $.23 * *$ & $.70 * *$ & I \\
\hline
\end{tabular}

$* p<.05 ; * * p<.01$.

and a significant effect of susceptibility on intention $(\beta=0.21, p<.01)$. The direct effect of the health message type by awareness status interaction effect was not significant $(\beta=0.03, p=.87$ ), nor were the two two-way interaction effects between health message type and susceptibility $(\beta=-0.06, p=.34)$ and awareness status and susceptibility $(\beta=-0.07, p=.30)$ or the three-way interaction effect between health message type, awareness status, and susceptibility $(\beta=-0.17, p=.17)$. These results seem to suggest a mediated-moderation effect in which the interaction effect of health message type and awareness status on intention is mediated by susceptibility. Performing Morgan-Lopez and MacKinnon's (2006) point estimator and standard error for the product of coefficients method, the estimate of the mediated-moderation effect was .06 and its standard error .11. Since mediated effects based on normal theory may provide biased confidence intervals, we calculated an asymmetric distribution to accurately determine the confidence interval for our estimate of the mediatedmoderation effect (see MacKinnon, Lockwood, Hoffman, West, \& Sheets, 2002; MacKinnon, Lockwood, \& Williams, 2004). To this end, we entered the estimates and standard errors of the effects of the health message type by awareness interaction effect on perceived susceptibility $(\beta=0.30, S E=.14)$ and of perceived susceptibility on intention $(\beta=0.21, S E=.07)$ in the PRODCLIN program (MacKinnon, Fritz, Williams, \& Lockwood, 2007). The resulting confidence interval ranged from 0.01 to 0.15 , indicating that the mediated-moderation effect was significant at the .05 level.

Concerning the role of personal relevance in explaining the effects of health message type on susceptibility (see Figure 3), we observed a significant health message type by awareness status interaction effect on personal relevance $(\beta=0.44, p=.03)$ and a significant main effect of personal relevance on susceptibility $(\beta=0.66, p<.0001)$. No interaction effect was observed between personal relevance and health message type or 


\section{Copyright (C) The British Psychological Society}

\section{Reproduction in any form (including the internet) is prohibited without prior permission from the Society}

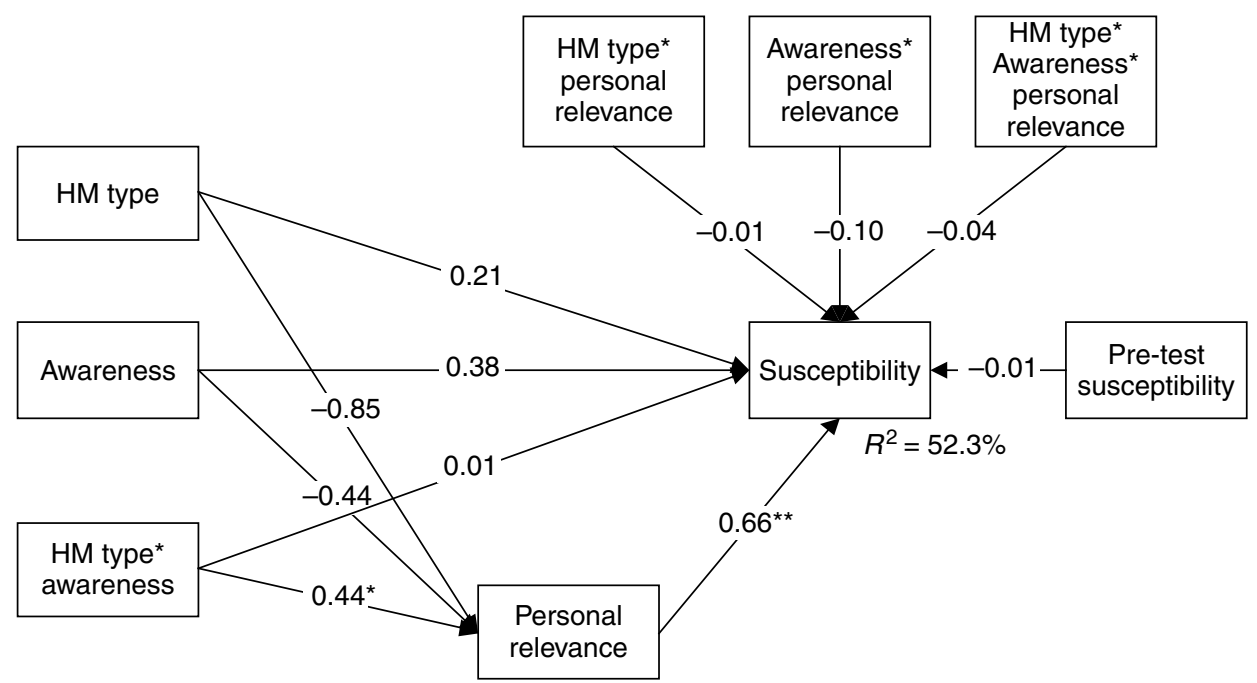

Figure 3. General model for testing mediation and moderation effects of personal relevance in the health message-susceptibility relationship. $*_{p}<.05 ;{ }^{* *} p<.01$.

awareness. The results thus seem to suggest a mediated-moderation effect in which the interaction effect of health message type and awareness status on susceptibility is mediated by personal relevance. Performing Morgan-Lopez and MacKinnon's (2006) point estimator and standard error for the product of coefficients method, the estimate of the mediated-moderation effect was .29 and its standard error .32. After entering the estimates and standard errors of the effects of the health message type by awareness interaction effect on personal relevance $(\beta=0.44, S E=.21)$ and of personal relevance on perceived susceptibility $(\beta=0.66, S E=.06)$ in the PRODCLIN program (MacKinnon et al., 2007), the resulting confidence interval ranged from 0.02 to 0.57 , indicating that the mediated-moderation effect was significant at the .05 level.

\section{Discussion}

The aims of this study were (1) to examine whether the general population accepts genetic health messages as credible and believable, (2) to examine whether they perceived genetic health messages as personally relevant, and (3) to explore the possible mediating or moderating effect of perceived personal relevance in the health message type-intention relationship. Concerning the first aim, the data do not support our hypotheses. We observed no effect of health message type or its interaction with awareness status on information acceptance. The genetic health message was accepted as well as the general health message by both previously aware and previously unaware participants. We did observe a health message type by awareness status interaction effect on perceived personal relevance. Participants reporting to be unaware of the existence of genetic risk factors for salt sensitivity prior to reading the HM were more inclined to perceive the general health message as personally relevant than the genetic health message confirming our Hypothesis 3. However, the results did not support Hypothesis 4 that aware participants would be more inclined to perceive as personally relevant the genetic message than the general message. 


\section{Copyright (C) The British Psychological Society \\ Reproduction in any form (including the internet) is prohibited without prior permission from the Society}

In fact, our findings seems to suggest that participants who were aware of the genetic risk factors for salt sensitivity (either prior to the study or while reading the genetic health message) perceived the message about salt sensitivity to be less personally relevant than participants who were and remained unaware of these factors. A recently proposed the materialist framework of lay knowledge of genetics (Condit et al., 2009) may shed some light on these results. According to this framework, people possess two mental models of disease causation: one describing genetic causation and the other describing behavioural causation. These two models are assumed to be unrelated and, as such, no mental model of gene-behaviour interaction causation exists. Importantly, for the present purpose, either one of these models can be activated upon proper cueing. The genetic health message may therefore have activated the 'genetic causation' mental model. Since the genetic causation model is not related to the behavioural causation model, the genetic health message may not have elicited consideration of the genebehaviour interaction. As such, message recipients may not be convinced that behaviour changes reduce their chance of developing hypertension as a result of salt consumption (Senior \& Marteau, 2007; Wright, French, Weinman, \& Marteau, 2006). This explanation is consistent with our finding that previously unaware individuals who read the genetic health message did not intend to restrict their salt consumption. However, knowing that the risk of having a genetic predisposition is, at least potentially, present may cause negative effect (Janoff-Bulman \& Lang-Gunn, 1988). Consequently, message recipients may use defensive coping strategies to reduce these feelings (Ruiter, Abraham, \& Kok, 2001), such as derogating personal relevance or underestimating personal susceptibility. Indeed, the observed effects of genetic health messages on intention were mediated by perceived susceptibility and personal relevance.

Notwithstanding the underlying cognitive processes, the results concerning our third aim showed that not perceiving the genetic health message to be personally relevant had an adverse influence on susceptibility and intention. Our results suggested the presence of a mediated-moderation effect, meaning that the health message type by awareness status interaction effect on perceived susceptibility was mediated by personal relevance. Our findings are largely consistent with the scarce previous research into the effects of genetic health messages, observing a negative effects of genetic health messages on susceptibility and intention (Cappella et al., 2005; Smerecnik, Mesters, de Vries, et al., 2009). The present results suggest that these effects may be explained by differential perceived personal relevance between general and genetic health messages. Previous research examining the relationship between personal relevance and perceived susceptibility suggests that individuals who do not perceive a health problem to be personally relevant are more likely to use heuristic strategies to determine susceptibility (Rothman \& Schwarz, 1998). As such, they are more likely to perceive lower personal susceptibility than those who do perceive a health problem to be personally relevant and as such use systematic strategies to arrive at a judgment.

Several implications for future research and practice can be deduced from our results. The present findings lend some weight to the concerns that media coverage of genetics may not be effective to promote precautionary action. That is, genetic health message may not be efficient in promoting preventive behaviour because they are not perceived as personally relevant. However, as stated, public education greatly benefits the technological applications of genomics (e.g., genetic testing) and should thus not be underestimated. Our findings suggest that 'adverse' effects of genetic health messages may be due to low perceived personal relevance of such messages. We may thus benefit from psychological research which has identified strategies to improve perceived 


\section{Copyright (C) The British Psychological Society \\ Reproduction in any form (including the internet) is prohibited without prior permission from the Society}

Chris M. R. Smerecnik et al.

personal relevance. According to the heuristic systematic model (Chaiken, Liberman, \& Eagly, 1989; Chen \& Chaiken, 1999), so-called heuristics (e.g., 'an expert is always right' or 'consensus implies correctness') can result in higher perceived personal relevance or susceptibility judgments regardless of its content. This seems especially relevant considering our discussion on the use of heuristic strategies to arrive at judgments of susceptibility. A promising factor influencing persuasion is source credibility. Recent research on the effects of source credibility on the persuasiveness of a message (Pornpitakpan, 2004) suggest that different sources are needed based on individuals' current beliefs about the role of genes in health and disease development. Message frequency may also play a role. As exposure increases, the uncertainty of a stimulus decreases and relevant characteristics of the message are more readily available for processing (Berlyne, 1970).

In addition to source credibility and message frequency, message framing has also been shown to affect perceived personal relevance. Message framing refers to the phenomenon that the same content can be 'framed' differently (Rothman \& Salovey, 1997). For instance, communicating that restricting salt intake influences hypertension can be framed as a gain (i.e., 'consuming little salt will decrease the blood pressure') or as a loss (i.e., 'consuming a lot of salt will increase the blood pressure'). Research into the effects of message framing on information acceptance and personal relevance has shown that gain-framed messages are more likely to be accepted as personally relevant than loss-framed messages (e.g., van 't Riet, Ruiter, Werrij, \& de Vries, 2010). If genetic health messages stress the gain of preventive behaviour in the face of genetic predispositions rather than (imply) the loss of personal control due to genetic predispositions (cf. Ugalde, Martin, \& Rees, 2008), such messages may be more readily perceived as personally relevant enhancing their effect on precautionary. Although this suggestion does not exactly parallel the definition of message framing, future research is suggested to assess the value of message framing for genetic health messages.

Our conclusions and implications for future research and practice need to be interpreted with some caution. Firstly, we assessed awareness of genetic risk factors for salt sensitivity in the socio-demographics questionnaire. Consequently, participants may have already formed expectations about the goal of the study prior to the experimental manipulation which could have biased the effects. However, the sociodemographics questionnaire was presented 1 month before the experimental manipulation which probably decreased any potential bias. Moreover, the results are consistent with previous research which assessed awareness status after the experimental manipulation at the end of the experiment (Smerecnik, Mesters, de Vries, et al., 2009). Secondly, perceived susceptibility was assessed using absolute and relative measures. However, recent research has shown that conditional measures are better suited to predict risk-behaviour change (Brewer, Chapman, Gibbons, Gerrard, \& McCaul, 2007). Since we were primarily interested in differences in perceived susceptibility between the genetic and the general health message rather than predicting health behaviour, our measures may have sufficed for this goal.

In conclusion, the present study suggests that being aware of the genetic risk factors of salt sensitivity results in lower perceived personal relevance of salt sensitivity. Under these conditions, we found adverse effects on susceptibility, intention, and preventive behaviour. Communication strategies that increase the perceived personal relevance of the message may be able to effectively reduce these adverse effects. Future research may try to identify and develop strategies to enhance perceived personal relevance thereby overcoming these adverse effects. The potential 


\title{
Copyright (C) The British Psychological Society
}

\author{
Reproduction in any form (including the internet) is prohibited without prior permission from the Society
}

of technological applications of genomics has long been recognized and with careful research into best practices of communicating such information this potential may be fully utilized.

\section{Acknowledgements}

This study was financially supported by Maastricht University. It was performed at the School for Public Health and Primary Care (Caphri), a part of The Netherlands School of Primary Care Research (CaRe), which was acknowledged by the Royal Netherlands Academy of Arts and Sciences (KNAW) in 1995. We thank Rik Crutzen and Jonathan van't Riet for their valuable comments on an earlier draft of this article.

\section{References}

Beeks, E., Kessels, A. G. H., Kroon, A. A., Van der Klauw, M. M., \& De Leeuw, P. W. (2004). Genetic predisposition to salt-sensitivity: A systematic review. Journal of Hypertension, 22, 1243-1249. doi:10.1097/01.hjh.0000125443.28861.0d

Berlyne, D. E. (1970). Novelty complexity and hedonic value. Perception and Psychophysics, 8, 279-286.

Brewer, N. T., Chapman, G. B., Gibbons, F. X., Gerrard, M., \& McCaul, K. D. (2007). Meta-analysis of the relationship between risk perception and health behavior: The example of vaccination. Health Psychology, 26, 136-145. doi:10.1037/0278-6133.26.2.136

Bubela, T. M., \& Caulfield, T. A. (2004). Do the print media 'Hype' genetic research? A comparison of newspaper stories and peer-reviewed research papers. Canadian Medical Association Journal, 170, 1399-1407. doi:10.1503/cmaj.1030762

Burke, W., Atkins, D., Gwinn, M., Guttmacher, A., Haddow, J., Lau, J., ... Wiesner, G. L. (2002). Genetic test evaluation: Information needs of clinicians, policy makers, and the public. American Journal of Epidemiology, 156, 311-318.

Butow, P. N., Lobb, E. A., Meiser, B., Barratt, A., \& Tucker, K. M. (2003). Psychological outcomes and risk perception after genetic testing and counselling in breast cancer: A systematic review. Medical Journal of Australia, 178, 77-81.

Cappella, J. N., Lerman, C., Romantan, A., \& Baruh, L. (2005). News about genetics and smoking: Priming, family smoking history, and news story believability on inferences of genetic susceptibility to tobacco addiction. Communication Research, 32, 478-502. doi:10.1177/0093650205277320

Chaiken, S., Liberman, A., \& Eagly, A. (1989). Heuristic and systematic information processing within and beyond the persuasion context. In J. S. Uleman \& J. A. Bargh (Eds.), Unintended thought (pp. 212-252). New York: The Guilford Press.

Chen, S., \& Chaiken, S. (1999). The heuristic-systematic model in its broader context. In S. Chaiken \& Y. Trope (Eds.), Dual-process theories in social psychology (pp. 73-96). New York: The Guilford Press.

Collins, F. S., Green, E. D., Guttmacher, A. E., \& Guyer, M. S. (2003). A vision for the future of genomics research. Nature, 422, 835-847. doi:10.1038/nature01626

Condit, C. M. (2005). Lay people actively process messages about genetic research. In E. F. Einsiedel \& F. Timmermans (Eds.), Crossing over: Genomics in the public arena (pp. 131-156). Calgary: University of Calgary Press.

Condit, C. M., Gronnwoll, M., Landau, J., Shen, L., Wright, L., \& Harris, T. M. (2009). Believing in both genetic determinism and behavioral action: A materialist framework and implications. Public Understanding of Science, 18(6), 730-746. doi:10.1177/0963662508094098

Fairchild, A. J., \& MacKinnon, D. P. (2009). A general model for testing mediation and moderation effects. Prevention Science, 10, 87-99. doi:10.1007/s11121-008-0109-6 


\section{Copyright (C) The British Psychological Society}

Reproduction in any form (including the internet) is prohibited without prior permission from the Society

Chris M. R. Smerecnik et al.

Frewer, L. J., Howard, C., Hedderley, D., \& Shepherd, R. (1999). Reactions to information about genetic engineering: Impact of source characteristics, perceived personal relevance, and persuasiveness. Public Understanding of Science, 8, 35-50. doi:10.1088/0963-6625/8/1/003

Guttmacher, A. E., \& Collins, F. S. (2005). Realizing the promise of genomics in biomedical research. Journal of the American Medical Association, 294, 1399-1402. doi:10.1001/jama. 294.11.1399

Janoff-Bulman, R., \& Lang-Gunn, L. (1988). Coping with disease, crime, and accidents: The role of self-blame attributions. In L. Y. Abramson (Ed.), Social cognition and clinical psychology: A synthesis (pp. 116-147). New York: The Guilford Press.

Janssens, A. C. J. W., \& Van Duijn, C. M. (2008). Genome-based prediction of common-diseases: Advances and prospects. Human Molecular Genetics, 17(2), 166-173. doi:10.1093/hmg/ $\operatorname{ddn} 250$

Katz Rothman, B. K. (1998). Genetic maps and human imaginations: The limits of science in understanding who we are. New York: W. W. Norton.

MacKinnon, D. P., Fritz, M. S., Williams, J., \& Lockwood, C. M. (2007). Distribution of the product confidence limits for the indirect effect: Program PRODCLIN. Behavior Research Methods, 39, 384-389.

MacKinnon, D. P., Lockwood, C. M., Hoffman, J. M., West, S. G., \& Sheets, V. (2002). A comparison of methods to test the significance of mediation and other intervening variables. Psychological Methods, 7, 83-104. doi:10.1037/1082-989X.7.1.83

MacKinnon, D. P., Lockwood, C. M., \& Williams, J. (2004). Confidence limits for the indirect effect: Distribution of the product and resampling methods. Multivariate Behavioral Research, 39, 99-128. doi:10.1207/s15327906mbr3901_4

Meiser, B., \& Halliday, J. L. (2002). What is the impact of genetic counseling in women at increased risk of developing hereditary breast cancer? A meta-analytic review. Social Science and Medicine, 54, 1463-1470. doi:10.1016/S0277-9536(01)00133-2

Morgan-Lopez, A. A., \& MacKinnon, D. P. (2006). Demonstration and evaluation of a method for assessing mediated moderation. Behavior Research Methods, 89, 852-863.

Muthen, B., \& Muthen, L. (2006). Mplus 4.2: Statistical software.

National Institutes for Health (2009). Human genome project - fact sheet (Vol. 2009).

NCBI (2009). Genetests-geneclinics. Retrieved from http://www.geneclinics.org

Pornpitakpan, C. (2004). The persuasiveness of source credibility: A critical review of five decades' evidence. Journal of Applied Social Psychology, 34, 243-281. doi:10.1111/j.15591816.2004.tb02547.x

Rogers, E. M. (2003). Diffusion of innovations (5th ed.). New York: Free Press.

Rothman, A. J., \& Salovey, P. (1997). Shaping perceptions to motivate healthy behavior: The role of message framing. Psychological Bulletin, 121, 3-19. doi:10.1037/0033-2909.121.1.3

Rothman, A. J., \& Schwarz, N. (1998). Constructing perceptions of vulnerability: Personal relevance and the use of experiential information in health judgments. Personality and Social Psychology Bulletin, 24, 1053-1064. doi:10.1177/01461672982410003

Ruiter, R. A. C., Abraham, C., \& Kok, G. (2001). Scary warnings and rational precautions: A review of the psychology of fear appeals. Psychology and Health, 16, 613-630. doi:10.1080/08870440108405863

Saab, P. G., McCalla, J. R., Coons, H. L., Christensen, A. J., Kaplan, R., Bennet Johnson, S., ... Melamed, B. (2004). Technological and medical advances: Implications for health psychology. Health Psychology, 23, 142-146.

Sanada, H., Yatabe, J., Midorikawa, S., Hashimoto, S., Watanabe, T., Moore, J. H., ... Felder R. A. (2006). Single-nucleotide polymorphisms for diagnosis of salt-sensitive hypertension. Clinical Chemistry, 52, 352-360.

Senior, V., \& Marteau, T. M. (2007). Causal attributions for raised cholesterol and perceptions of effective risk-reduction: Self-regulation strategies for an increased risk of coronary heart disease. Psychology and Health, 22, 699-717. doi:10.1080/14768320601020253 


\title{
Copyright (C) The British Psychological Society
}

\author{
Reproduction in any form (including the internet) is prohibited without prior permission from the Society
}

Smerecnik, C. M. R., Mesters, I., de Vries, N. K., \& de Vries, H. (2009). Alerting the general public to genetic risks: The value of health messages communicating the existence of genetic risk factors for public health promotion. Health Psychology, 28, 734-745. doi:10.1037/a0016386

Smerecnik, C. M. R., Mesters, I., Verweij, E., de Vries, N., \& de Vries, H. (2009). A systematic review of the impact of genetic counseling on risk perception accuracy. Journal of Genetic Counseling, 18, 217-228. doi:10.1007/s10897-008-9210-z

Ugalde, A., Martin, P., \& Rees, G. (2008). Psychological impact of receiving genetic risk information for breast cancer, with and without lifestyle information. Australian Journal of Psychology, 60, 1-9. doi:10.1080/00049530701449497

van 't Riet, J., Ruiter, R. A. C., Werrij, M. Q., \& de Vries, H. (2010). Self-efficacy moderates messageframing effects: The case of skin-cancer detection. Psychology and Health, 25(3), 339-349. doi:10.1080/08870440802530798

Wang, C., Bowen, D. J., \& Kardia, S. L. R. (2005). Research and practice opportunities at the intersection of health education, health behavior, and genomics. Health Education and Behavior, 32, 686-701. doi:10.1177/1090198105278827

Wright, A. J., French, D. P., Weinman, J., \& Marteau, T. M. (2006). Can genetic risk information enhance motivation for smoking cessation? An analogue study. Health Psychology, 25, 740-752. doi:10.1037/0278-6133.25.6.740

Received 7 October 2009; revised version received 22 February 2010 


\section{Copyright (C) The British Psychological Society}

Reproduction in any form (including the internet) is prohibited without prior permission from the Society

\section{Appendix}

\section{Stimulus materials}

Genetic health message

Researchers have announced that blood pressure responses to salt intake vary between individuals. Until fairly recently, salt intake was assumed to cause elevated blood pressure. The research team, however, has identified a gene which contributes to elevated blood pressure in response to salt intake.

Hypertension is an important risk factor for cardiovascular disease. In other words, if you are hypertensive, your risk of cardiovascular disease will increase. Hypertension is caused by life-style and environmental factors. The relationship between elevated blood pressure and salt intake, a life-style factor, is well known. However, researchers have announced that this relationship does not apply to everyone. 'Not everyone is sensitive to salt intake', according to the project leader. 'People without a genetic predisposition to salt-sensitive blood pressure may consume salt as usual.'

The research team advises people with salt-sensitive blood pressure to restrict their salt intake in order to reduce their risk of cardiovascular disease.

\section{General health message}

Researchers have announced that blood pressure responses to salt intake vary between individuals. Until fairly recently, salt intake was assumed to cause elevated blood pressure.

Hypertension is an important risk factor for cardiovascular disease. In other words, if you are hypertensive, your risk of cardiovascular disease will increase. Hypertension is caused by life-style and environmental factors. The relationship between elevated blood pressure and salt intake is well known. However, researchers have announced that this relationship does not apply to everyone. 'Not everyone is sensitive to salt intake', according to the project leader. 'People without salt-sensitive blood pressure may consume salt as usual'.

The research team advises people with salt-sensitive blood pressure to restrict their salt intake in order to reduce their risk of cardiovascular disease. 